\title{
Orientation behaviour of Culicoides obsoletus (Diptera: Ceratopogonidae), a relevant virus vector in northern Europe, toward host-associated odorant cues
}

\author{
Jean-Yves Zimmer*, François J. Verheggen, Eric Haubruge, Frédéric Francis \\ Functional and Evolutionary Entomology, Gembloux Agro-Bio Tech, University of Liege, Passage des Déportés 2, B-5030 Gembloux, Belgium
}

\section{A R T I C L E I N F O}

\section{Article history:}

Received 20 September 2014

Received in revised form 11 May 2015

Accepted 12 May 2015

\section{Keywords:}

Host preferences

Culicoides obsoletus

Vectors

Flight tunnel

Olfactometer

Odours

\begin{abstract}
A B S T R A C T
Some Culicoides biting midge species (Diptera: Ceratopogonidae) are biological virus vectors worldwide and have recently been associated with outbreaks of important epizootic diseases such as bluetongue and Schmallenberg in northern Europe. These diseases, which affect domestic and wild ruminants, have caused considerable economic losses. Knowledge of host preferences of these biting midges - especially of the relevant vectors of arboviruses near farms, such as Culicoides obsoletus in northern Europe - is essential to understand pathogen transmission cycles and the epidemiology of associated diseases. This study aimed to determine host preferences of $C$. obsoletus using an in-field flight tunnel containing pairs of calf, sheep, chicken, and human hosts (and controls) and a laboratory two-choice bioassay containing volatile extracts of host skin (and controls). Behavioural responses of nulliparous $C$. obsoletus females in the in-field flight tunnel showed a preference for human (but also calf and sheep) hosts, probably due to their exhalation of greater quantities of carbon dioxide. The laboratory experiment revealed that volatile organic compounds released from the skin of chicken and sheep seemed to attract this species. Culicoides obsoletus, thus, seems to have a wide host range and to be particularly attracted by humans under field conditions. A better understanding of vector-host interaction could enable the development of control strategies against adult biting midges, by exploiting insect-repelling or -attractive semiochemicals. Volatile extracts of chicken and/or sheep skin could be used to identify volatile compounds attractive to C. obsoletus, which in turn could be used in baited traps.
\end{abstract}

(c) 2015 Elsevier B.V. All rights reserved.

\section{Introduction}

Bluetongue (BT) and Schmallenberg diseases (SB) have been reported in northern Europe in recent years (Thiry et al., 2006; Hoffmann et al., 2012). BT is an infectious and non-contagious disease first described in South Africa (Anon., 1876), of which serotype 8 was detected for the first time in northern Europe in August 2006 (Thiry et al., 2006). Bluetongue virus (BTV) affects domestic and wild ruminants. The risk of the emergence of new serotypes or viral recombination was highlighted through analysis of the multiple incursions of BT in Europe (Saegerman et al., 2008). In 2011, a new animal virus belonging to the Simbu serogroup and named Schmallenberg virus (SBV) was also detected in this part of the continent (Hoffmann et al., 2012). This virus, which affects ruminants, caused

\footnotetext{
* Corresponding author. Tel.: +32 816226 61; fax: +32 81622312 .

E-mail addresses: Jean-Yves.Zimmer@alumni.ulg.ac.be, entomologie.gembloux@ulg.ac.be (J.-Y.Zimmer).
}

decreased milk production, diarrhoea and fever (Hoffmann et al., 2012). Abortions, stillbirths and severe congenital malformations were also reported (Herder et al., 2012; Van den Brom et al., 2012). These outbreaks have spread quickly throughout a large portion of the European Union and have caused considerable direct and indirect economic losses in the sheep and cattle industries, although the scale of these losses is difficult to assess (Saegerman et al., 2008; Velthuis et al., 2010; Conraths et al., 2012).

Biological vectors of these arboviruses are bloodsucking midges (ranging from 1 to $4 \mathrm{~mm}$ in length) of the genus Culicoides Latreille 1809 (Diptera: Ceratopogonidae). About 1400 species of this genus have been recorded throughout the world (Borkent, 2014). Only females of some Culicoides species, however, act as vectors of pathogens (viruses, protozoa and filarial nematodes) of medical and veterinary importance (Mellor et al., 2000; Elbers et al., 2013). These biting midges have recently been associated with outbreaks of important viral epizoonoses in northern Europe (BT and SB). Moreover, the bites of hematophagous females are known to be a source of nuisance; their presence can thus hinder the economic 
development of some regions, hampering agricultural and forestry activities as well as tourism (Hendry and Godwin, 1988).

Outbreaks and the rapid spread of viral diseases highlight the lack of knowledge about these vectors (especially for Palaearctic species), in particular their distribution and larval ecology, but mainly host preferences. Although some Culicoides species are autogenous, the females of most species require a blood meal to facilitate egg maturation (Kettle, 1962; Glukhova and Dubrovskaia, 1972; Mellor et al., 2000). In general, many hematophagous species (such as mosquitoes and Culicoides) prefer a specific host on which they will feed (Kettle, 1962; Bartsch et al., 2009; Votypka et al., 2009; Lassen et al., 2012; Viennet et al., 2013), although some species are known to be generalists (Blackwell et al., 1994). Some Culicoides species, however, exhibit opportunistic feeding behaviour with respect to host distribution and density (Kettle, 1977; Garros et al., 2011; Lassen et al., 2011, 2012; Calvo et al., 2012). Visual stimuli and body odour are the two main elements involved in attraction to hosts (Bishop et al., 2008). Host visibility and characteristics (e.g. shape, colour, size and contrast) may affect their attractiveness to some biting midges (Humphreys and Turner, 1973; Tanner and Turner, 1974; Koch and Axtell, 1979; Braverman et al., 2003; Bishop et al., 2008). Culicoides biting midges have olfactory structures (antennal and maxillary receptors) for the detection of volatile compounds, and thus, host location (Bowen, 1991; Gibson and Torr, 1999; Grant and Kline, 2003; Logan and Birkett, 2007). A diversity of host-derived products perceived by olfaction (e.g. carbon dioxide, 1-octen-3-ol, lactic acid, phenols, acetone) may, thus, attract hematophagous insects (Nelson, 1965; Kline et al., 1994; Ritchie et al., 1994; Blackwell et al., 1996; Gibson and Torr, 1999; Bhasin et al., 2000b, 2001; Marquardt et al., 2000; Braverman et al., 2000; Cilek and Kline, 2002; Grant and Kline, 2003; Mordue, 2003; Mands et al., 2004; Logan and Birkett, 2007; Harrup et al., 2012). Volatile organic compounds (VOCs) attracting these biting midges, however, remain poorly documented.

Studies aiming to identify the host preferences of Culicoides biting midges have mainly used two types of approach. Several studies have identified the origin of blood present in the abdomen of adult females that have recently fed - which represent a very small proportion of any collection (Service, 1969) - to determine the host range (Blackwell et al., 1994; Bartsch et al., 2009; Garros et al., 2011; Lassen et al., 2011, 2012; Ninio et al., 2011; Calvo et al., 2012; Martinez-de la Puente et al., 2012; Pettersson et al., 2013). Other researchers have collected Culicoides adult females directly from animals used as bait, predominantly with sticky traps or by aspiration (Viennet et al., 2011, 2013; Ayllón et al., 2014). Behavioural studies using olfactometers or wind or flight tunnels in which a specific number of biting insects are released are very rare (Bhasin et al., 2000b) due to the difficulty of obtaining a sufficient number of insects, given the complexity of maintaining many Culicoides species of interest under controlled conditions. Only a few species of limited interest in northern Europe - are commonly bred (Jones, 1964; Fahrner and Barthelmess, 1988; Kremer and Lienhart, 1998), and these do not include species of the subgenus Avaritia (particularly Culicoides obsoletus Meigen 1818), considered to be vectors of BTV and SBV (Mehlhorn et al., 2007; Carpenter et al., 2008; Hoffmann et al., 2009; De Regge et al., 2012; Elbers et al., 2013).

Many studies of mosquito host preferences have been conducted (Lyimo and Ferguson, 2009), but very few have examined the preferences of biting midges, particularly Palaearctic species. Knowledge of host range and host preferences, and an understanding of host-seeking behaviour of the most abundant Culicoides species near northern European farms, C. obsoletus (Baldet et al., 2008; Takken et al., 2008; Mehlhorn et al., 2009; Zimmer et al., 2009, 2013b,d, 2014b), are essential. This information will allow a better understanding of vector-host interaction, the transmission cycle of pathogens, and the epidemiology of associated diseases.
Thus, this behavioural study aimed to identify the attractiveness of host associated cues for C. obsoletus using two bioassays: an infield flight tunnel containing live hosts, and a laboratory two-choice olfactometer with volatile extracts of host skin.

\section{Material and methods}

\subsection{Hosts}

The host choice behaviour of $C$. obsoletus was evaluated toward four hosts: calf, sheep, human and chicken. The calf was a white and black Holstein heifer, aged about 1 month and weighing about $50 \mathrm{~kg}$. The sheep was a Roux Ardennais ewe, aged about 1.5 years and weighing about $60 \mathrm{~kg}$; it had been shorn one month before the experiment. The human was a 29-year-old European male weighing about $70 \mathrm{~kg}$. A group of 12 hens aged about 1.5 years was used in this study. These hosts were not dipped or treated with any insecticides or fly repellents. All possible combinations of host pairs, as well as combinations of each host with a control (no animal), were used. A double control condition (no animal) was used to validate the results. A total of 11 combinations were thus evaluated.

\subsection{Collection of adult female Culicoides}

Given the difficulty of artificially rearing C. obsoletus - the most abundant northern European species - and the need for a large number of newly hatched nulliparous females, all individuals used in the bioassays were collected from their larval development sites. Four emergence traps, each covering an area of $0.32 \mathrm{~m}^{2}$, were placed $24 \mathrm{~h}$ before each experiment above different types of silage residue on a Belgian cattle farm in Jemeppe-sur-Sambre (Namur Province; $50^{\circ} 28^{\prime} \mathrm{N}, 4^{\circ} 40^{\prime} \mathrm{E}$ ) (Zimmer et al., 2008, 2013a,c). On the morning of each test day, Culicoides biting midges that had emerged overnight were collected alive using a mouth-operated aspirator and stored in a cage net. All Culicoides specimens used in the experiments thus came from the same substrate on the same cattle farm, and had emerged within the previous $24 \mathrm{~h}$.

\subsection{In-field flight tunnel}

In order to evaluate the attractiveness of live hosts towards $C$. obsoletus females in a natural habitat, we have installed a large flight tunnel in a meadow. The biting midges were, thus, in the presence of odour cues released from the hosts' skin and emitted during respiration, excretion and/or digestion, as well as those produced by the hosts' trampling of grass.

The in-field flight tunnel consisted of two wooden boxes (each $2 \mathrm{~m}$ long, $1.5 \mathrm{~m}$ wide, $1.5 \mathrm{~m}$ high) with walls made of tarpaulins attached with Velcro on all sides. The interiors of the tarpaulins were black to provide a dark environment suited to the predominantly crepuscular nature of Culicoides (Mellor et al., 2000), and the exteriors were white to minimise the thermal effects of the sun. The two boxes were connected by an opaque plastic tube $(12 \mathrm{~cm}$ in diameter and $1.5 \mathrm{~m}$ long), which had a central opening with a cover allowing the introduction of a defined number of biting midges into the tunnel. Each box contained a metal cage about $1 \mathrm{~m}$ high in which the hosts were confined (Fig. 1). The device was built in a meadow in the immediate vicinity of the cattle farm, and behavioural tests were conducted between 14 June and 9 October 2012; these in-field tests were performed between 11 a.m. and 4 p.m.

Three replicates of each experiment implicating each host combination were performed, yielding a total of 33 experiments. One replicate consisted in analysing the choice behaviour of $100 \mathrm{C}$. obsoletus in the tunnel. In each experiment, the hosts were placed in the boxes $15 \mathrm{~min}$ before the release of $C$. obsoletus specimens within the central (neutral) area of the device. The insects were allowed to fly 


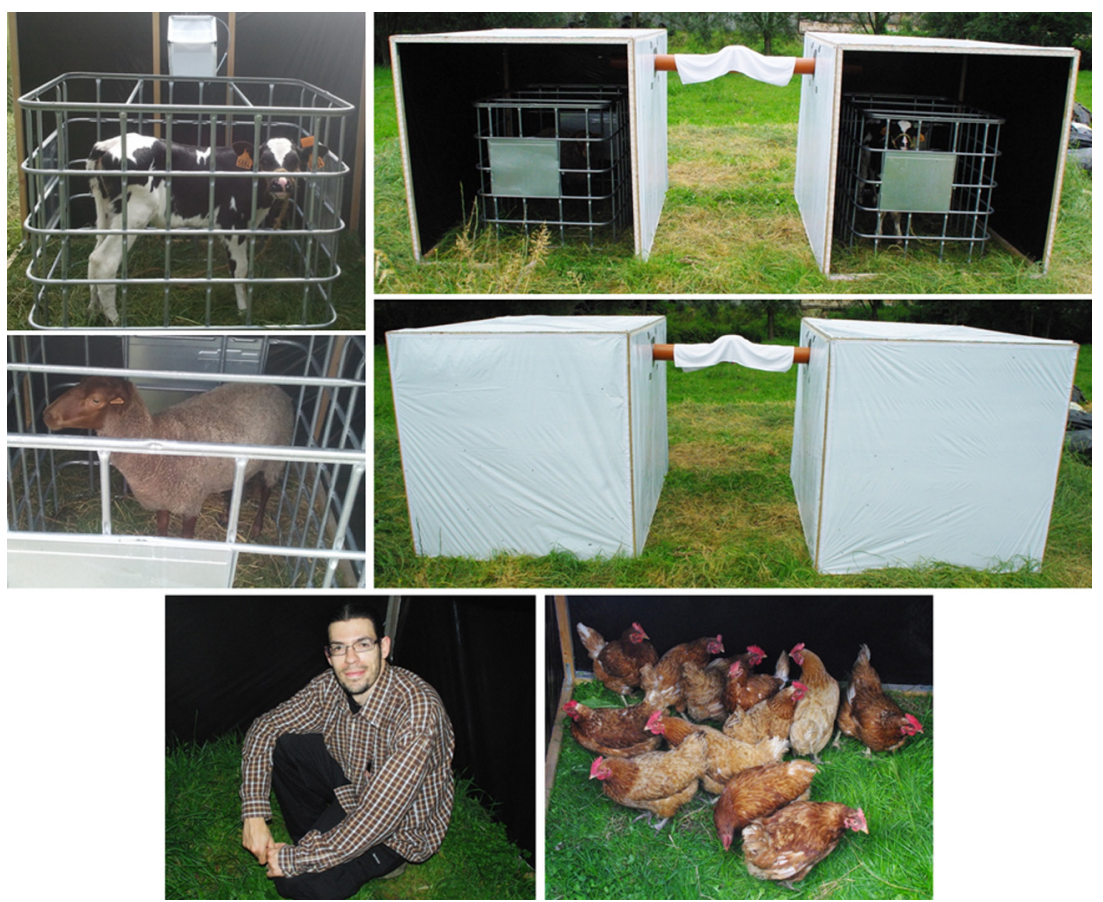

Fig. 1. In-field flight tunnel used in the meadow of a cattle farm, and tested hosts.

for $45 \mathrm{~min}$ in any of the two directions. Preliminary tests indicated that this period of time was sufficient to allow most of the biting midges to explore the arena. However, the Culicoides individuals were not able to get in physical contact with the hosts as they were collected in net cages positioned at the outlets of the tube connecting the two boxes; they also could not return to the central area after reaching the boxes housing the hosts. The temperatures and light conditions in the two boxes were similar for each test. The hosts were positioned randomly for each experiment and the corresponding tarpaulins were also moved; after each experiment, the tarpaulins were washed with hot water. The entire device was repositioned in the meadow for each test.

This experiment was approved by the ethics committee of the University of Liege.

\subsection{Laboratory two-choice bioassay}

In the laboratory two-choice bioassay, we evaluated the attractiveness of volatile extracts of animal skin toward $C$. obsoletus. The feeding preferences of $C$. obsoletus were examined in the laboratory between 4 September and 1 October 2013, in the dark to avoid external bias caused by the influence of light intensity on the behaviour of the midges and to coincide with the predominantly crepuscular nature of these biting midges (Mellor et al., 2000). We used a glass olfactometer (total length, $60 \mathrm{~cm}$ ) consisting of three sections: a central area with an opening allowing the insertion of a determinate number of Culicoides biting midges into the device, and two side areas (Fig. 2). Insects were allowed to fly towards one of the two side areas, where the cues were placed. Each opposite area was separated from the central area with a funnel-shaped glass wall, allowing the insects to enter one of the side area, but reducing the possibility to return to the central area.

\subsubsection{Collection of the VOCS}

Two volatile collections were conducted simultaneously by air entrainment from the same specimen of each host. The host animals were kept in empty stables on the farm in Jemeppe-sur-Sambre. Odour extracts were taken directly from the surface of each host's skin at the belly and flank levels using pull air pumps (Escort Elf ${ }^{\circledR}$ Pump; MSA, Pittsburgh, PA, USA) providing a constant airflow at the rate of $1.0 \mathrm{~L} / \mathrm{min}$. Volatile extracts of host skin were collected over a $1 \mathrm{~h}$ period across $60 \mathrm{mg}$ SuperQ ${ }^{\circledR}$ glass traps (Alltech, Deerfield, IL, USA) connected with a Teflon ${ }^{\circledR}$ pipe to the pumps, and terminated by a glass funnel placed in contact with the skin. Two control odour samples were collected simultaneously in a second stable containing no animals. After sample collection, the extremities of the traps were protected with a Teflon ${ }^{\circledR}$ strip and the traps were wrapped in aluminium foil to avoid contamination.

After transport to the laboratory, each glass trap was eluted with $400 \mu \mathrm{L} n$-hexane (95\% pure; Sigma-Aldrich, St. Louis, MO, USA) Elutions of the two odour samples from each host were combined to homogenise the sample, which was stored in closed vials wrapped with Teflon ${ }^{\circledR}$ strips at $-80^{\circ} \mathrm{C}$. Elutions of all samples were concentrated to $200 \mu \mathrm{L}$ using a gentle nitrogen stream. While wearing gloves, researchers deposited $10 \mu \mathrm{L}$ of each concentrated sample onto a $1 \mathrm{~cm}^{2}$ piece of filter paper, which was then placed in a glass Petri dish. Each dish containing a sample was then placed under a laboratory air aspiration system for 1 min to allow partial evaporation of the solvent, and finally placed at the extremity of the two-choice olfactometer.

\subsubsection{Experimental device}

The disposition of odour extracts in the laboratory two-choice bioassay was determined randomly before each test, and the

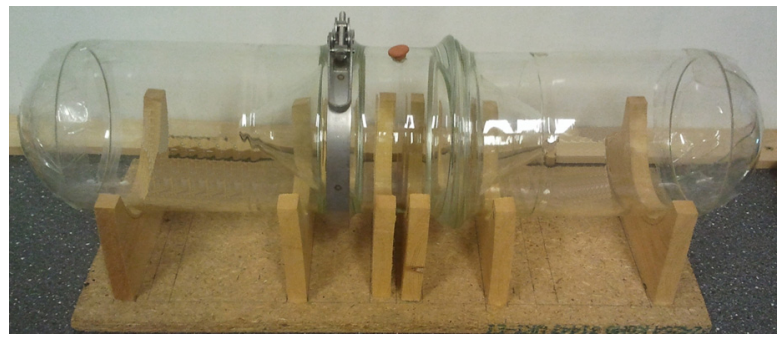

Fig. 2. Laboratory two-choice olfactometer. 


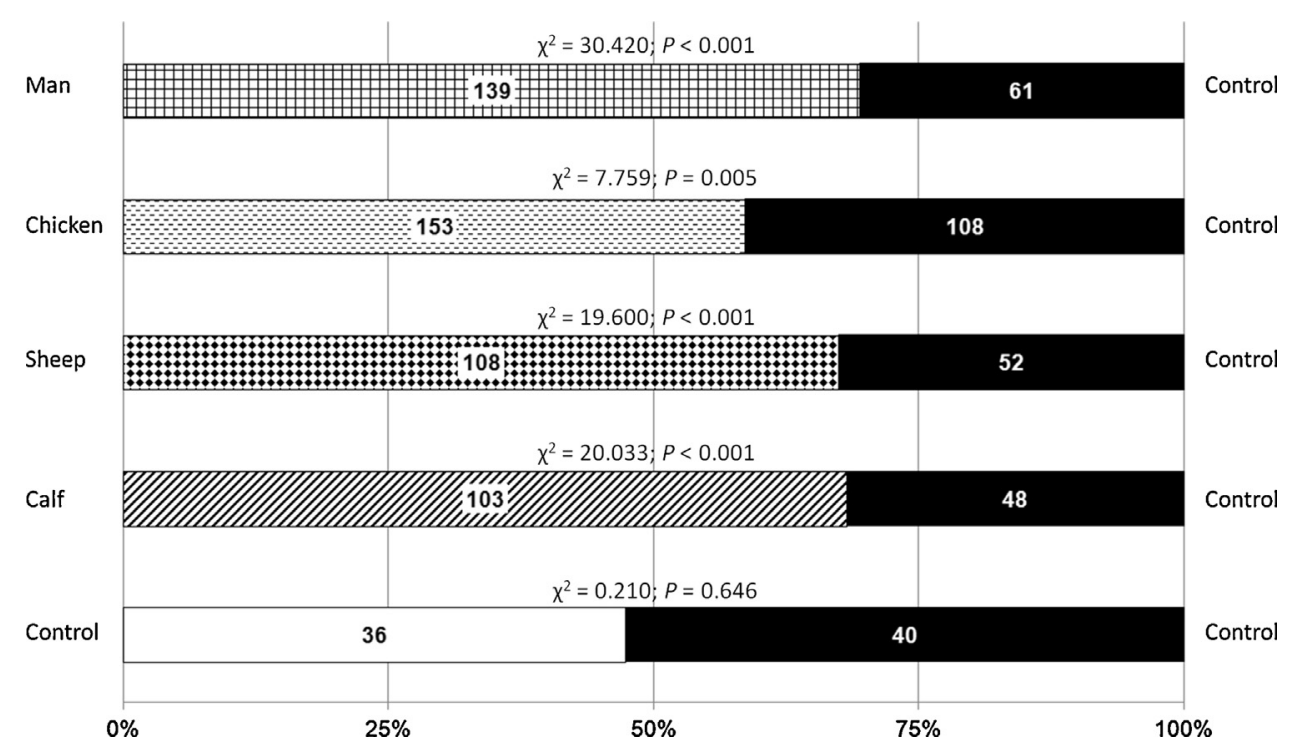

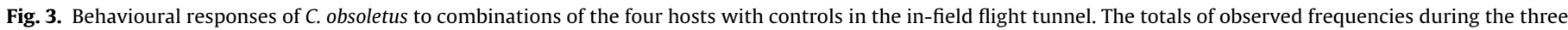
replicates and results of the $\chi^{2}$ test are presented for each combination.

olfactometer was oriented randomly in the laboratory. For each experiment, 40 nulliparous Culicoides females collected in the field with emergence traps, were inserted in the central area of the experimental device and given $45 \mathrm{~min}$ to select a side area. In addition to the 11 host combinations, a supplementary combination of the control odour sample and pure $n$-hexane was tested. Four replicates of each combination were performed, yielding a total of 48 experiments. After each experiment, the olfactometer was washed with a cloth soaked with $n$-hexane under a laboratory air aspiration system, and the SuperQ ${ }^{\circledR}$ glass traps were washed with $600 \mu \mathrm{L}$ dichloromethane then $600 \mu \mathrm{L} n$-hexane.

\subsection{Culicoides identification}

Culicoides biting midges used in each field and laboratory host preference experiment were collected after testing with a mouth-operated aspirator and preserved in annotated receptacles containing $80 \%$ ethanol to allow further identification. All collected insects were observed under a stereomicroscope (10-40× magnification) to verify that they were females belonging to the two species of the Obsoletus complex (C. obsoletus and Culicoides scoticus Downes and Kettle 1952); the few male specimens and those belonging to other species (mainly Culicoides chiopterus Meigen 1830 and Culicoides dewulfi Goetghebuer 1936) were removed from the data set. Preliminary morphological identification was conducted using the key of Delécolle (1985).

Females of the two Obsoletus complex species were slide mounted and observed under a microscope (100-400× magnification) to distinguish them morphologically (Augot et al., 2010; Nielsen and Kristensen, 2011). Finally, specimens of the species $C$. obsoletus obtained in each iteration of the behavioural tests were counted.

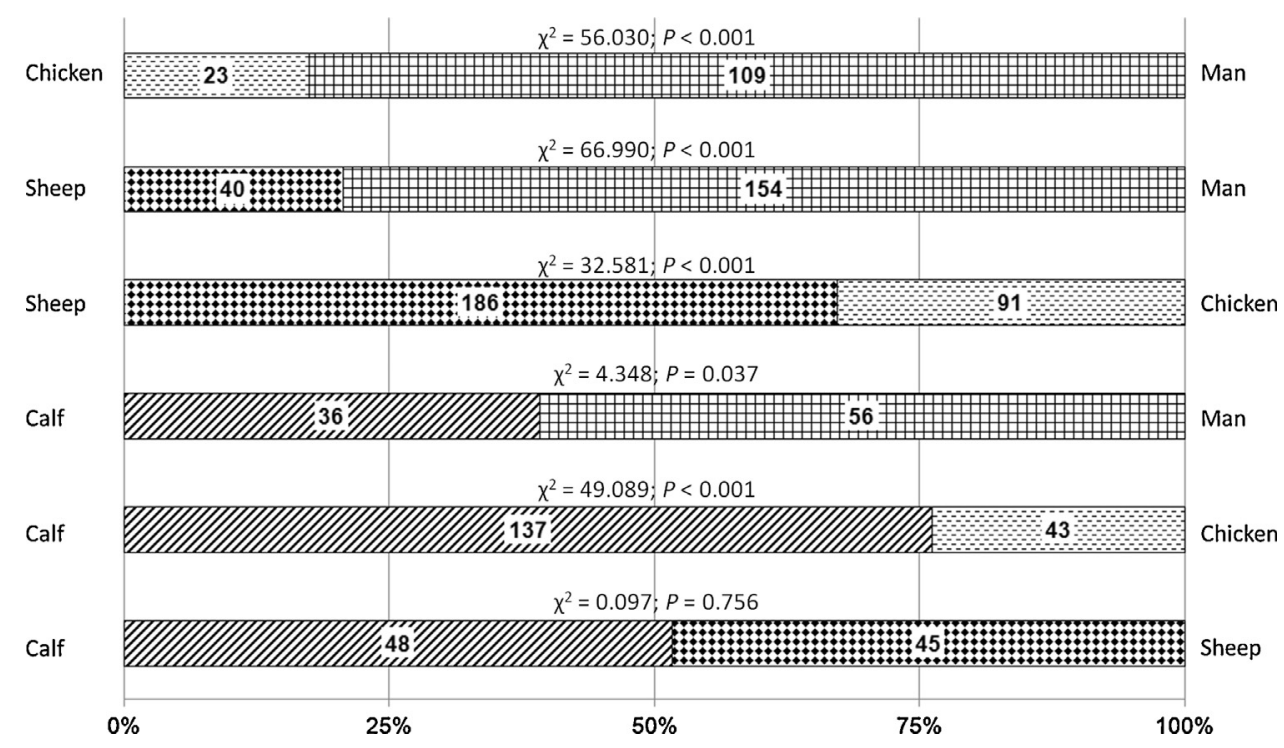

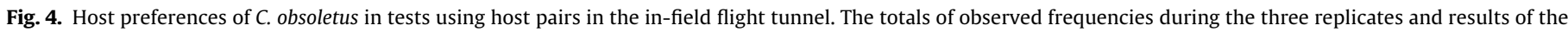
$\chi^{2}$ test are presented for each combination. 


\subsection{Statistical analysis}

Observed frequencies of host selection of $C$. obsoletus females were compared to the corresponding theoretical frequencies using the $\chi^{2}$ test. These tests were performed using MINITAB ${ }^{\circledR}$ software (version 16; State College, PA, USA), with significance defined as $P \leq 0.05$.

\section{Results}

\subsection{In-field flight tunnel}

The behavioural responses of nulliparous $C$. obsoletus females presented with combinations of single hosts and controls, as well as under double control conditions are illustrated (Fig. 3). No preference for either of the two in-field flight tunnel extremities was observed in the absence of a host (double control test; $\chi^{2}=0.210$, $P=0.646$ ); the majority (74\%) of Culicoides specimens remained in the central area. The biting midges exhibited strong attraction to all hosts tested in combination with a control; $51-89 \%$ of the insects made selections during these tests.

Host preferences in dual choice experiments are presented (Fig. 4). The biting midges showed very strong preferences for calf and sheep over chicken, and for human over sheep and chicken $\left(\chi^{2}=32.581-66.990, P<0.001\right) ; 45-94 \%$ of the biting midges made host selections in these experiments. A significant preference for human over calf was observed $\left(\chi^{2}=4.348, P=0.037\right.$ ), although only $31 \%$ of tested Culicoides made host selections in this experiment. In contrast, no preference between calf and sheep was observed $\left(\chi^{2}=0.097, P=0.756\right)$, although $68 \%$ of insects selected a host in this experiment.

\subsection{Laboratory two-choice bioassay}

The behavioural responses of nulliparous $C$. obsoletus females exposed to a single animal odour source, as well as to the controls are shown (Fig. 5). The double control test confirmed the absence of a preference for either side of the laboratory olfactometer $\left(\chi^{2}=0.375, P=0.540\right) ; 38 \%$ of tested insects made no choice. The control odour seemed to be more attractive than $n$-hexane or $n$-hexane seemed to be repellent $\left(\chi^{2}=5.940, P=0.015\right)$. The biting midges showed very strong preference for all four volatile extracts of animal skin over the control odour, although the calf odour seemed to be much less attractive than the other host odours; $75-86 \%$ of insects made selections during these tests.

Host preferences in experiments conducted with double odour combinations are illustrated (Fig. 6). Volatile extract of calf odour was much less attractive than those of sheep, human and chicken $\left(\chi^{2}=6.950-19.843, P \leq 0.008\right)$. C. obsoletus females also showed a very strong preference for volatile extracts of chicken skin over human skin $\left(\chi^{2}=9.529, P=0.002\right) ; 76-86 \%$ of biting midges made host selections in these tests. A significant preference for sheep over human $\left(\chi^{2}=4.760, P=0.029\right)$ was also observed and more than $89 \%$ of insects made host selections in this experiment. Finally, similar numbers of Culicoides preferred the volatile extracts of sheep and chicken skin $\left(\chi^{2}=0.862, P=0.353\right) ; 73 \%$ of biting midges made host selections during this test.

\section{Discussion}

The acquisition of a large number of $C$. obsoletus specimens - as required for the two behavioural tests undertaken in this study of host preferences using emergence traps placed on silage residues confirmed the abundance of this species in this substrate (Zimmer et al., 2008, 2013a,c, 2014a,c).
The behavioural responses of $C$. obsoletus in the absence of any visual stimulus in both experimental settings showed that they were attracted to VOCs associated with hosts. These VOCs can be derived from the hosts' skin (as in the laboratory experiment) or may correspond to other molecules related to an "animal system" (e.g. carbon dioxide emitted during respiration, urine or faeces produced during the field experiment).

Larger percentages of Culicoides biting midges made selections during the laboratory than during the field experiments, likely due to the greater travel distance required to select a host in the in-field flight tunnel compared with the laboratory two-choice bioassay. The field experiment required the maintenance of a limited range of temperature inside the device, not only to ensure the well-being of the hosts, but also to avoid adverse effects on Culicoides activity.

In the field, volatile molecules released by an animal located in the meadow or stable diluted in a particularly important surrounding air volume. In contrast, the small, sealed two-choice olfactometer used in the laboratory contained a much smaller air volume. In this device, the released insects were nearer to the odour source compare to the field tests. Thus, a lower concentration of odours than observed in the natural field setting should be sufficient for the laboratory experiment. Researchers must ensure that they use an odour concentration sufficient for Culicoides detection and thereby generate realistic responses, while also taking care not to use a concentration so high that it alters the insects' reaction.

Host preferences observed in these two behavioural experiments differed substantially. The field experiment indicated that C. obsoletus females preferred the human host over sheep, calf and chicken, with calf and sheep seeming to be similarly attractive and chicken appearing to be least attractive. In contrast, the laboratory experiment showed that the biting midges preferred the volatile extracts of sheep and chicken skin over those of calf and human, with sheep and chicken eliciting similar responses and calf appearing to be least attractive. The preference for large animals (particularly the human, but also calf and sheep) in the field experiment could be explained by these hosts' exhalation of greater quantities of carbon dioxide (Koch and Axtell, 1979) in the enclosure; note that their body surface areas are quite similar. However, the laboratory experiment showed that Culicoides were more attracted to VOCs released from the skin of sheep and chickens.

The attraction of Culicoides biting midges to 1-octen-3-ol, carbon dioxide, phenol and lactic acid, presented alone or in combination, in the absence of a light source (Kline et al., 1994; Ritchie et al., 1994; Gibson and Torr, 1999; Braverman et al., 2000; Marquardt et al., 2000; Cilek and Kline, 2002; Mordue, 2003; Mands et al., 2004) or combined with a light trap (Wieser-Schimpf et al., 1991; Venter et al., 2011), is well known. Bhasin et al. (2000b) studied the responses of Culicoides impunctatus Goetghebuer 1920 to acetone, carbon dioxide and 1-octen-3-ol in a wind tunnel. Antenna stimulation in response to 1 -octen-3-ol and carbon dioxide has been examined using electrophysiology or electroantennography (Blackwell et al., 1996; Bhasin et al., 2000a; Grant and Kline, 2003; Sollai et al., 2007). The release rate of these chemicals was found to influence Culicoides attraction (Ritchie et al., 1994; Braverman et al., 2000), and the combination of these chemicals may have a synergistic (or antagonistic) effect (Ritchie et al., 1994; Cilek and Kline, 2002). Moreover, interaction (attraction or repellent) may exist between host-derived VOCs and parous female pheromones (Blackwell et al., 1996).

The attraction of a Culicoides species to a particular host is not necessarily associated with feeding on that host, as noted for $C$. dewulfi (Viennet et al., 2011) and C. chiopterus (Garros et al., 2011). Most species of the genus Culicoides are known to be either mammalophilic (Hair and Turner, 1968; Foxi and Delrio, 2010; Garros et al., 2011; Calvo et al., 2012) or ornithophilic (Bennett, 1960; Hair and Turner, 1968; Garvin and Greiner, 2003; Mullens et al., 2006; 


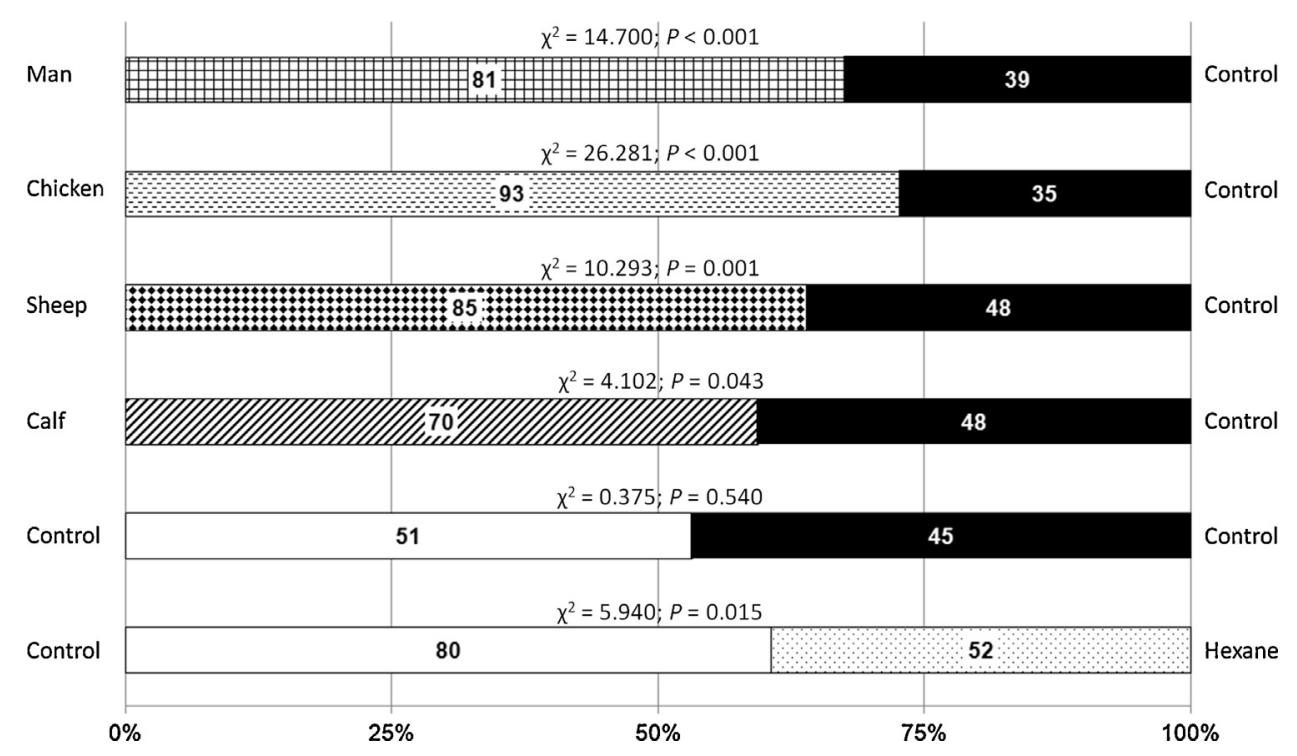

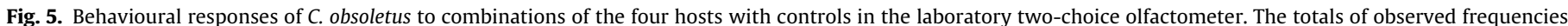
during the four replicates and results of the $\chi^{2}$ test are presented for each combination.

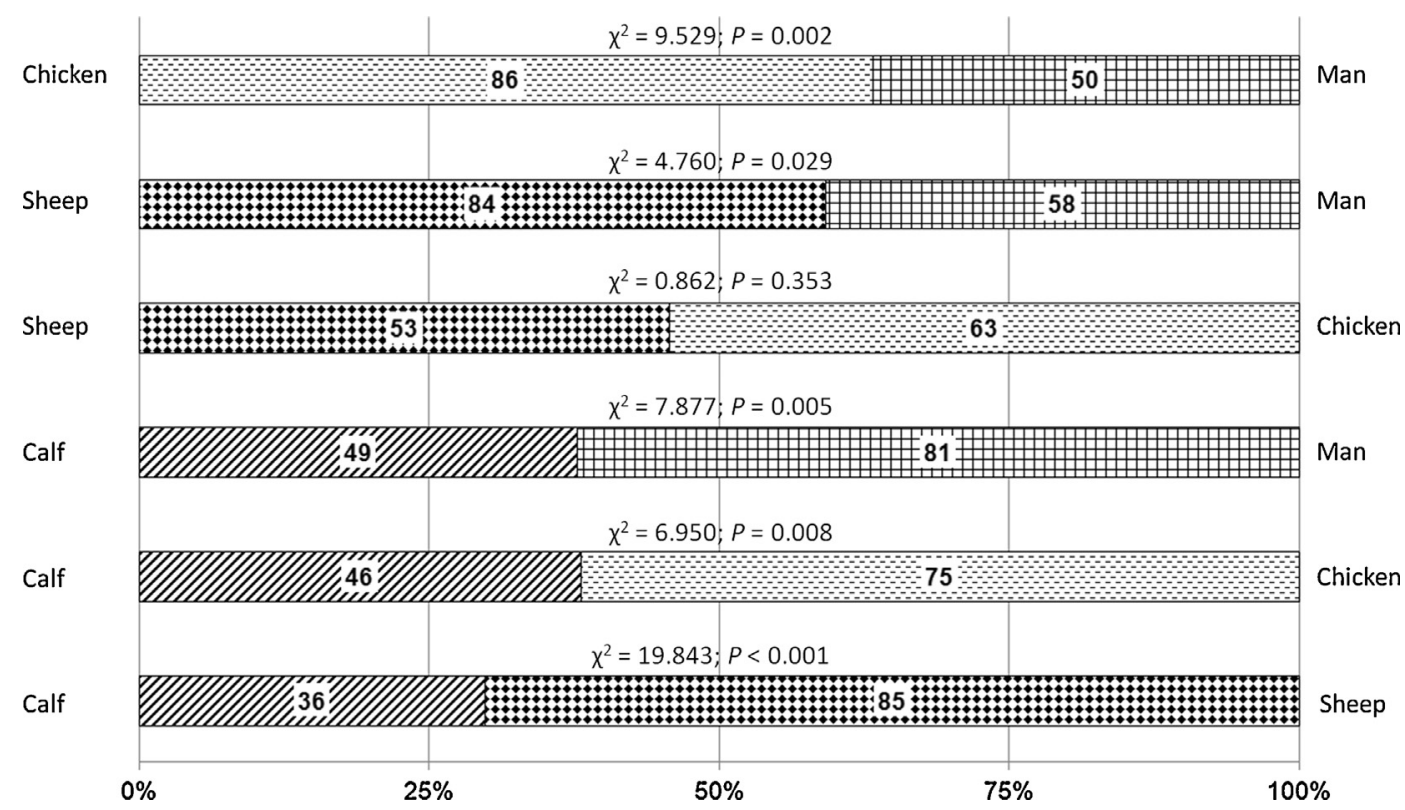

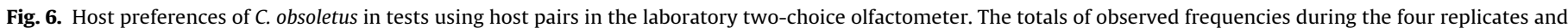
results of the $\chi^{2}$ test are presented for each combination.

Martinez-de la Puente et al., 2009; Votypka et al., 2009; Foxi and Delrio, 2010; Cerny et al., 2011), although some feed on reptiles or frogs. In a previous study using animal-baited traps, horses were found to be the most attractive hosts for the three main Palaearctic Culicoides species, including C. obsoletus (Viennet et al., 2013). C. obsoletus followed by Culicoides pulicaris L. 1758 was also the most abundant species found on horses (Van der Rijt et al., 2008). Van der Rijt et al. (2008) also reported that host infectious status affects host location by vectors, as suggested by Torres-Estrada and Rodriguez (2003) and Lacroix et al. (2005). C. obsoletus also seemed to be attracted to heifer, goat and ewe, as well as birds (Viennet et al., 2013), although this species is considered to be strictly mammalophilic (Lassen et al., 2012). While some Culicoides species are opportunistic, most Palaearctic species appear to prefer cattle (Bartsch et al., 2009; Lassen et al., 2011; Ninio et al., 2011). Ninio et al. (2011) identified the blood of horse, rabbit, pig, sheep and human in the abdomens of blood-fed C. obsoletus females, whereas Pettersson et al. (2013) observed the blood of sheep, cattle and horse. This species, thus, seems to feed on a wide range of mammals (Lassen et al., 2012) but to prefer cattle, even when other hosts are present in adjacent areas (Bartsch et al., 2009). Biting records of C. obsoletus have also been compiled for humans (Atchley, 1967). According to Parker (1949), C. impunctatus - which is very common in bogs, especially in Belgium (Zimmer et al., 2013b) - was 10 times more attracted to humans than was C. obsoletus.

As suggested by Tanner and Turner (1974), host choice is also influenced by the height at which a Culicoides species searches. In addition to host preference, the parts of host bodies attacked may differ among Culicoides species (Kettle, 1962; Nielsen, 1971; Viennet et al., 2013; Ayllón et al., 2014), especially due to variations in hair density and skin temperature. For example, C. obsoletus seems to feed preferentially on the belly regions of cattle and sheep 
(Nielsen, 1971; Schmidtmann et al., 1980). In addition to visual stimuli (e.g. shape, colour, size and contrast), which seem to influence the attraction of some Culicoides species (Humphreys and Turner, 1973; Tanner and Turner, 1974; Koch and Axtell, 1979; Braverman et al., 2003; Bishop et al., 2008), the potential influences of host age, sex and diet on the insects' behavioural responses cannot be excluded.

Virus dispersal may be enhanced by Culicoides feeding on multiple host species (Mellor et al., 2000; Calvo et al., 2012), and wild ruminants may serve as reservoirs for viruses (Linden et al., 2008). Moreover, these biting midges are able to take blood from engorged mosquitoes, and this indirect acquisition of vertebrate blood could also play a role in pathogen transmission cycles (Kremer et al., 1974; Ma et al., 2013).

\section{Conclusion and perspectives}

Culicoides obsoletus - a major species of interest for virus transmission in northern Europe (Carpenter et al., 2008; De Regge et al., 2012) - seems to have a wide host range, and is likely to be particularly interested in humans under field conditions. This species showed mammalophilic preferences (mainly for humans) in the field experiments - probably caused by greater emission of carbon dioxide - but ornithophilic and mammalophilic preferences (chicken and sheep) based on VOCs released from skin surfaces in the laboratory experiments.

The use of an in-field flight tunnel is an original approach to the evaluation of a given species' host preferences under conditions approximating a real field setting. Knowledge of host range and host preferences is necessary for a better understanding of vector-host interactions, pathogen transmission cycles and the epidemiology of associated diseases.

The laboratory two-choice bioassay allowed identification of the most attractive odours (using volatile extracts of host skin) for the Culicoides species tested. The composition of these odour extracts could be analysed by gas chromatography-mass spectrometry (Logan and Birkett, 2007). This approach would allow selection and testing of molecules of interest by electrophysiology or electroantennography to evaluate their perception by selected insect models. Semiochemicals of interest could ultimately be used to develop artificial push-pull control strategies (Mordue and Mordue, 2003; Logan and Birkett, 2007). Insect-repelling compounds could be used to repel Culicoides from potential hosts, thereby avoiding attack, and attractive compounds could be used as bait to attract biting insects (Logan and Birkett, 2007). For this last objective, volatile extracts of chicken or/and sheep skin could be used to identify VOCs that are attractive to C. obsoletus.

These elements could, thus, be used to develop control strategies against these vectors. The mechanisms of animal host location and selection of hosts for feeding, as well as the feeding patterns of these vectors, must be investigated.

\section{Conflict of interest}

The authors declare the existence of no competing interests.

\section{Acknowledgements}

The authors are grateful to Grégory Simonon (Functional and Evolutionary Entomology, Gembloux Agro-Bio Tech, University of Liege, Belgium) for help with construction of the in-field flight tunnel, and Pr Yves Brostaux (Applied Statistics, Computer Science and Mathematics, Gembloux Agro-Bio Tech, University of Liege, Belgium) for help with the development of the experimental protocol. The authors also thank the University of Liege's Ethics
Committee who given a favourable opinion to the realisation of this study, and the farmer who allowed access to his cattle farm and provided the animals used for behavioural tests in the field.

\section{References}

Anon., New disease. In: Report of the South African cattle and sheep disease commission Report 16 1876; 189-194.

Atchley, W.R., 1967. The Culicoides of New Mexico (Diptera: Ceratopogonidae). Univ. Kansas Sci. Bull. 46, 937-1020.

Augot, D., Sauvage, F., Jouet, D., Simphal, E., Veuille, M., Couloux, A., Kaltenbach, M.L., Depaquit, J., 2010. Discrimination of Culicoides obsoletus and Culicoides scoticus potential bluetongue vectors, by morphometrical and mitochondrial cytochrome oxidase subunit I analysis. Infect. Genet. Evol. 10, 629-637.

Ayllón, T., Nijhof, A.M., Weiher, W., Bauer, B., Allène, X., Clausen, P.H., 2014. Feeding behaviour of Culicoides spp. (Diptera: Ceratopogonidae) on cattle and sheep in northeast Germany. Parasit. Vectors 7, 34, http://dx.doi.org/10.1186/ 1756-3305-7-34

Baldet, T., Delécolle, J.-C., Cêtre-Sossah, C., Mathieu, B., Meiswinkel, R., Gerbier, G., 2008. Indoor activity of Culicoides associated with livestock in the bluetongue virus (BTV) affected region of northern France during autumn 2006. Prev. Vet. Med. 87 (1-2), 84-97.

Bartsch, S., Bauer, B., Wiemann, A., Clausen, P.H., Steuber, S., 2009. Feeding patterns of biting midges of the Culicoides obsoletus and Culicoides pulicaris groups on selected farms in Brandenburg, Germany. Parasitol. Res. 105 (2), 373-380, http://dx.doi.org/10.1007/s00436-009-1408-y

Bennett, G.F., 1960. On some ornithophilic blood-sucking diptera in Algonquin Park, Ontario, Canada. Can. J. Zool. 38, 377-389.

Bhasin, A., Mordue (Luntz), A.J., Mordue, W., 2000a. Electrophysiological and behavioural identification of host kairomones as olfactory cues for Culicoides impunctatus and C. nubeculosus. Physiol. Entomol. 25, 6-16.

Bhasin, A., Mordue (Luntz), A.J., Mordue, W., 2000b. Responses of the biting midge Culicoides impunctatus to acetone, $\mathrm{CO}_{2}$ and 1-octen-3-ol in a wind tunnel. Med. Vet. Entomol. 14 (3), 300-307.

Bhasin, A., Mordue (Luntz), A.J., Mordue, W., 2001. Field studies on efficacy of host odour baits for the biting midge Culicoides impunctatus in Scotland. Med. Vet. Entomol. 15 (2), 147-156.

Bishop, A.L., McKenzie, H.J., Spohr, L.J., 2008. Attraction of Culicoides brevitarsis Kieffer (Diptera: Ceratopogonidae) and Culex annulirostris Skuse (Diptera: Culicidae) to simulated visual and chemical stimuli from cattle. Aust. J. Entomol. 47, 121-127.

Blackwell, A., Mordue (Luntz), A.J., Mordue, W., 1994. Identification of bloodmeals of the Scottish biting midge, Culicoides impunctatus, by indirect enzyme-linked immunosorbent assay (ELISA). Med. Vet. Entomol. 8 (1), 20-24.

Blackwell, A., Dyer, C., Mordue (Luntz), A.J., Wadhams, L.J., Mordue, W., 1996. The role of 1-octen-3-ol as a host-odour attractant for the biting midge, Culicoides impunctatus Goetghebuer, and interactions of 1-octen-3-ol with a volatile pheromone produced by parous female midges. Physiol. Entomol. 21 (1), 15-19.

Borkent, A., 2014. World Species of Biting Midges (Diptera: Ceratopogonidae), http://wwx.inhs.illinois.edu/files/9913/9144/3328/CeratopogonidaeCatalog. pdf

Bowen, M.F., 1991. The sensory physiology of host-seeking behavior in mosquitoes. Annu. Rev. Entomol. 36, 139-158.

Braverman, Y., Wegis, M.C., Mullens, B.A., 2000. Response of Culicoides sonorensis (Diptera: Ceratopogonidae) to 1-octen-3-ol and three plant-derived repellent formulations in the field. J. Am. Mosq. Contr. 16 (2), 158-163.

Braverman, Y., Rechtman, S., Frish, A., Braverman, R., 2003. Dynamics of biting activity of $C$. imicola Kieffer (Diptera: Ceratopogonidae) during the year. Isr. J. Vet. Med. 58, 46-56.

Calvo, J.H., Berzal, B., Calvete, C., Miranda, M.A., Estrada, R., Lucientes, J., 2012. Host feeding patterns of Culicoides species (Diptera: Ceratopogonidae) within the Picos de Europa National Park in northern Spain. Bull. Entomol. Res. 102 (6), 692-697, http://dx.doi.org/10.1017/S0007485312000284

Carpenter, S., McArthur, C., Selby, R., Ward, R., Nolan, D.V., Mordue (Luntz), A.J., Dallas, J.F. Tripet, F., Mellor, P.S., 2008. Experimental infection studies of UK Culicoides species midges with bluetongue virus serotypes 8 and 9. Vet. Rec. 163, 589-592, http://dx.doi.org/10.1136/vr.163.20.589

Cerny, O., Votypka, J., Svobodova, M., 2011. Spatial feeding preferences of ornithophilic mosquitoes: blackflies and biting midges. Med. Vet. Entomol. 25, 104-108.

Cilek, J.E., Kline, D.L., 2002. Adult biting midge response to trap type, carbon dioxide, and an octenol/phenol mixture in northwestern Florida. J. Am. Mosq. Contr. 18 (3), 228-231.

Conraths, F., Eschbaumer, M., Freuling, C., Gethmann, J., Hoffmann, B., Kramer, M., Probst, C., Staubach, C., Beer, M., 2012. Bluetongue disease: an analysis of the epidemic in Germany 2006-2009. In: Mehlhorn, H. (Ed.), Arthropods as Vectors of Emerging Diseases, Parasitology Research Monographs. Springer, Berlin, Heidelberg, pp. 103-135.

De Regge, N., Deblauwe, I., De Deken, R., Vantieghem, P., Madder, M., Geysen, D. Smeets, F., Losson, B., Van den Berg, T., Cay, A.B., 2012. Detection of Schmallenberg virus in different Culicoides spp. by real-time RT-PCR Transbound. Emerg. Dis., http://dx.doi.org/10.1111/tbed.12000 
Delécolle, J-C., (Thèse d'Université) 1985. Nouvelle contribution à l'étude systématique et iconographique des espèces du genre Culicoides (Diptera: Ceratopogonidae) du Nord-Est de la France. Université Louis Pasteur de Strasbourg, UFR des Sciences de la Vie et de la Terre, Strasbourg, France, 238 pp.

Elbers, A.R.W., Meiswinkel, R., van Weezep, E., Sloet van Oldruitenborgh-Oosterbaan, M.M., Kooi, E.A., 2013. Schmallenberg virus in Culicoides spp. biting midges, the Netherlands, 2011. Emerg. Infect. Dis. 19, 106-109.

Fahrner, J., Barthelmess, C., 1988. Rearing of Culicoides nubeculosus (Diptera: Ceratopogonidae) by natural or artificial feeding in the laboratory. Vet. Parasitol. 28 (4), 307-313.

Foxi, C., Delrio, G., 2010. Larval habitats and seasonal abundance of Culicoides biting midges found in association with sheep in northern Sardinia Italy. Med. Vet. Entomol. 24, 199-209.

Garros, C., Gardès, L., Allène, X., Rakotoarivony, I., Viennet, E., Rossi, S., Balenghien T., 2011. Adaptation of a species-specific multiplex PCR assay for the identification of bloodmeal source in Culicoides (Ceratopogonidae: Diptera): applications on Palaearctic biting midge species, vectors of Orbiviruses. Infect. Genet. Evol. 11, 1103-1110.

Garvin, M.C., Greiner, E.C., 2003. Ecology of Culicoides (Diptera: Ceratopogonidae) in southcentral Florida and experimental Culicoides vectors of the avian hematozoan Haemoproteus danilewskyi Kruse. J. Wildl. Dis. 39, 170-178.

Gibson, G., Torr, S.J., 1999. Visual and olfactory responses of haematophagous Diptera to host stimuli. Med. Vet. Entomol. 13, 2-23.

Glukhova, V.M., Dubrovskaia, V.V., 1972. Autogenic maturation of the eggs of bloodsucking midges (Diptera: Ceratopogonidae). Parazitologiia 6 (4), 309-319.

Grant, A.J., Kline, D.L., 2003. Electrophysiological responses from Culicoides (Diptera: Ceratopogonidae) to stimulation with carbon dioxide. J. Med. Entomol. 40, 284-293.

Hair, J.A., Turner, E.C., 1968. Preliminary host preference studies on Virginia Culicoides (Diptera: Ceratopogonidae). Mosq. News 28, 103-107.

Harrup, L.E., Logan, J.G., Cook, J.I., Golding, N., Birkett, M.A., Pickett, J.A., Sanders, C. Barber, J., Rogers, D.J., Mellor, P.S., Purse, B.V., Carpenter, S., 2012. Collection of Culicoides (Diptera: Ceratopogonidae) using $\mathrm{CO}_{2}$ and enantiomers of 1-octen-3-ol in the United Kingdom. J. Med. Entomol. 49 (1), 112-121.

Hendry, G., Godwin, G., 1988. Biting midges in Scottish forestry: a costly irritant or a trivial nuisance? Scot. Forest 42, 113-119.

Herder, V., Wohlsein, P., Peters, M., Hansmann, F., Baumgärtner, W., 2012. Salient lesions in domestic ruminants infected with the emerging so-called Schmallenberg virus in Germany. Vet. Pathol. 49, 588-591.

Hoffmann, B., Bauer, B., Bauer, C., Bätza, H.-J., Beer, M., Clausen, P.-H., Geier, M., Gethmann, J.M., Kiel, E., Liebisch, G., Liebisch, A., Mehlhorn, H., Schaub, G.A., Werner, D., Conraths, F.J., 2009. Monitoring of putative vectors of bluetongue virus serotype 8, Germany. Emerg. Infect. Dis. 15 (9), 1481-1484.

Hoffmann, B., Scheuch, M., Höper, D., Jungblut, R., Holsteg, M., Schirrmeier, H. Eschbaumer, M., Goller, K.V., Wernike, K., Fischer, M., Breithaupt, A., Mettenleiter, T.C., Beer, M., 2012. Novel orthobunyavirus in cattle, Europe, 2011. Emerg. Infect. Dis. 18 (3), 469-472, http://dx.doi.org/10.3201/eid1803. 111905

Humphreys, J.G., Turner, E.C., 1973. Blood-feeding activity of female Culicoides (Diptera: Ceratopogonidae). J. Med. Entomol. 10 (1), 79-83.

Jones, R.H., 1964. Mass production methods in rearing Culicoides variipennis (Coquillett). Bull. Wld. Hlth. Org 31, 571-572

Kettle, D.S., 1962. The bionomics and control of Culicoides and Leptoconops (Diptera: Ceratopogonidae = Heleidae). Annu. Rev. Entomol. 7, 401-418.

Kettle, D.S., 1977. Biology and bionomics of bloodsucking Ceratopogonids. Annu. Rev. Entomol. 22, 33-51.

Kline, D.L., Hagan, D.V., Wood, J.R., 1994. Culicoides responses to 1-octen-3-ol and carbondioxide in salt marshes near Sea Island, Georgia, USA. Med. Vet. Entomol. 8 (1), 25-30.

Koch, H.G., Axtell, R.C., 1979. Attraction of Culicoides furens and C. hollensis (Diptera: Ceratopogonidae) to animal hosts in a salt marsh habitat. J. Med. Entomol. 15 (5-6), 494-499.

Kremer, M., Lienhart, E., 1998. Elevage de Culicoides nubeculosus (Diptera: Ceratopogonidae). Parasite 5 (3), 211-214.

Kremer, M., Molet, B., Rebholtz-Hirtzel, C., Delécolle, J.-C., 1974. Culicoides nubeculosus (Ceratopogonidae) feeding on engorged Aedes aegypti under laboratory conditions. Mosq. News 34 (4), 471-472.

Lacroix, R., Mukabana, W.R., Gouagna, L.C., Koella, J.C., 2005. Malaria infection increases attractiveness of humans to mosquitoes. PLoS Biol. 3, 1590-1593.

Lassen, S.B., Nielsen, S.A., Skovgard, H., Kristensen, M., 2011. Molecular identification of bloodmeals from biting midges (Diptera: Ceratopogonidae: Culicoides Latreille) in Denmark. Parasitol. Res. 108 (4), 823-829.

Lassen, S.B., Nielsen, S.A., Kristensen, M., 2012. Identity and diversity of blood meal hosts of biting midges (Diptera: Ceratopogonidae: Culicoides Latreille) in Denmark. Parasit. Vectors 5, 143, http://dx.doi.org/10.1186/1756-3305-5-143

Linden, A., Mousset, B., Grégoire, F., Hanrez, D., Vandenbussche, F., Vandemeulebroucke, E., Vanbinst, T., Verheyden, B., de Clerck, K., 2008. Bluetongue virus antibodies in wild red deer in southern Belgium. Vet. Rec. 162,459

Logan, J.G., Birkett, M.A., 2007. Semiochemicals for biting fly control: their identification and exploitation. Pest. Manag. Sci. 63, 647-657.

Lyimo, I.N., Ferguson, H.M., 2009. Ecological and evolutionary determinants of host species choice in mosquito vectors. Trends Parasitol. 25 (4), 189-196.
Ma, Y., Xu, J., Yang, Z., Wang, X., Lin, Z., Zhao, W., Wang, Y., Li, X., Shi, H., 2013. A video clip of the biting midge Culicoides anophelis ingesting blood from an engorged Anopheles mosquito in Hainan, China. Parasit. Vectors 6, 326.

Mands, V., Kline, D.L., Blackwell, A., 2004. Culicoides midge trap enhancement with animal odour baits in Scotland. Med. Vet. Entomol. 18, 336-342.

Marquardt, W.C., Demaree, R.S., Grieve, R.B., 2000. Parasitology and Vector Biology, Second Edition. Academic Press, San Diego, 702 pp.

Martinez-de la Puente, J., Martinez, J., Ferraguti, M., Morales-de la Nuez, A., Castro, N., Figuerola, J., 2012. Genetic characterization and molecular identification of the bloodmeal sources of the potential bluetongue vector Culicoides obsoletus in the Canary Islands, Spain. Parasit. Vectors 5, 147, http://dx.doi.org/10.1186/ 1756-3305-5-147

Martinez-de la Puente, J., Merino, S., Tomas, G., Moreno, J., Morales, J., Lobato, E., Talavera, S., Monteys, V.S.I., 2009. Factors affecting Culicoides species composition and abundance in avian nests. Parasitology 136 (9), 1033-1041.

Mehlhorn, H., Walldorf, V., Klimpel, S., Jahn, B., Jaeger, F., Eschweiler, J., Hoffmann, B., Beer, M., 2007. First occurrence of Culicoides obsoletus-transmitted Bluetongue virus epidemic in Central Europe. Parasitol. Res. 101, 219-228, http://dx.doi.org/10.1007/s00436-007-0519-6

Mehlhorn, H., Walldorf, V., Klimpel, S., Schaub, G., Kiel, E., Focke, R., Liebisch, G. Liebisch, A., Werner, D., Bauer, C., Clausen, H., Bauer, B., Geier, M., Hörbrand, T., Bätza, H.J., Conraths, F.J., Hoffmann, B., Beer, M., 2009. Bluetongue disease in Germany (2007-2008): monitoring of entomological aspects. Parasitol. Res. $105,313-319$

Mellor, P.S., Booman, J., Baylis, M., 2000. Culicoides biting midges: their role as arbovirus vectors. Annu. Rev. Entomol. 45, 307-340, http://dx.doi.org/10.1146/ annurev.ento.45.1.307

Mordue (Luntz), A.J., 2003. Arthropod semiochemicals: mosquitoes, midges and sealice. Biochem. Soc. Trans. 31, 128-133.

Mordue (Luntz), A.J., Mordue, W., 2003. Biting midge chemical ecology. Biologist $50,159-162$.

Mullens, B.A., Cardona, C.J., McClellan, L., Szijj, C.E., Owen, J.P., 2006. Culicoides bottimeri as a vector of Haemoproteus lophortyx to quail in California. U. S. A. Vet. Parasitol. 140, 35-43.

Nelson, R.L., 1965. Carbon dioxide as an attractant for Culicoides. J. Med. Entomol. 2, 56-57.

Nielsen, B.O., 1971. Some observations on biting midges (Diptera: Ceratopogonidae) attacking grazing cattle in Denmark. Ent. Scand. 2, 94-98.

Nielsen, S.A., Kristensen, M., 2011. Morphological and molecular identification of species of the Obsoletus group (Diptera: Ceratopogonidae) in Scandinavia. Parasitol. Res. 109, 1133-1141.

Ninio, C., Augot, D., Delécolle, J.-C., Dufour, B., Depaquit, J., 2011. Contribution to the knowledge of Culicoides (Diptera: Ceratopogonidae) host preferences in France. Parasitol. Res. 108 (3), 657-663, http://dx.doi.org/10.1007/s00436-010-2110-9

Parker, A.H., 1949. Observations on the seasonal and daily incidence of certain biting midges (Culicoides Latreille-Diptera; Ceratopogonidae) in Scotland. Trans. R. Entomol. Soc. Lond. 100, 179-190.

Pettersson, E., Bensch, S., Ander, M., Chirico, J., Sigvald, R., Ignell, R., 2013. Molecular identification of bloodmeals and species composition in Culicoides biting midges. Med. Vet. Entomol. 27 (1), 104-112, http://dx.doi.org/10.1111/j. 1365-2915.2012.01038.x

Ritchie, S.A., Van Essen, P.H.A., Kemme, J.A., Kay, B.H., Allaway, D., 1994. Response of biting midges (Diptera: Ceratopogonidae) to carbon dioxide, octenol, and light in southeastern Queensland, Australia. J. Med. Entomol. 31, 645-648.

Saegerman, C., Berkvens, D., Mellor, P.S., Dal Pozzo, F., Porter, S., Zientara, S., 2008 Fièvre catarrhale ovine: l'Europe au carrefour de l'enzootie. Point Vét. 290, 41-47.

Schmidtmann, E.T., Jones, C.J., Gollands, B., 1980. Comparative host-seeking attractivity of Culicoides (Diptera: Ceratopogonidae) attracted to pastured livestock in Central New York State. U. S. A. J. Med. Entomol. 17, 221-231.

Service, M.W., 1969. Light trap catches of Culicoides spp. from southern England. Bull. Entomol. Res. 59, 317-322.

Sollai, G., Solari, P., Masala, C., Crnjar, R., Liscia, A., 2007. Effects of avermectins on olfactory responses of Culicoides imicola (Diptera: Ceratopogonidae). J. Med. Entomol. 44, 656-659.

Takken, W., Verhulst, N., Scholte, E.J., Jacobs, F., Jongema, Y., van Lammeren, R., 2008. The phenology and population dynamics of Culicoides spp. in different ecosystems in The Netherlands. Prev. Vet. Med. 87 (1-2), 41-54.

Tanner, G.D., Turner, J.E.C., 1974. Vertical activities and host preferences of several Culicoides species in a southwestern Virginia Forest. Mosq. News 34 (1), 66-70.

Thiry, E., Saegerman, C., Guyot, H., Kirten, P., Losson, B., Rollin, F., Bodmer, M. Czaplicki, G., Toussaint, J.F., De Clercq, K., De Dochy, J.M., Dufey, J., Gilleman, J.L., Messeman, K., 2006. Bluetongue in northern Europe. Vet. Rec. 159, 327, http://dx.doi.org/10.1136/vr.159.10.327

Torres-Estrada, J.L., Rodriguez, M.H., 2003. Physic-chemical signals involved in host localization and induction of disease vector mosquito bites. Salud Publica de Mex. 45 (6), 497-505.

Van den Brom, R., Luttikholt, S.J., Lievaart-Peterson, K., Peperkamp, N.H., Mars, M.H., van der Poel, W.H., Vellema, P., 2012. Epizootic of ovine congenital malformations associated with Schmallenberg virus infection. Tijdschr. Diergeneeskd. 137, 106-111.

Van der Rijt, R., van den Boom, R., Jongema, Y., van Oldruitenborgh-Oosterbaan, M.M., 2008. Culicoides species attracted to horses with and without insect hypersensitivity. Vet. J. 178 (1), 91-97. 
Velthuis, A.G., Saatkamp, H.W., Mourits, M.C., de Koeijer, A.A., Elbers, A.R., 2010. Financial consequences of the Dutch bluetongue serotype 8 epidemics of 2006 and 2007. Prev. Vet. Med. 93 (4), 294-304

Venter, G.J., Labuschagne, K., Boikanyo, S.N., Majatladi, D.M., Morey, L., 2011. The effect of 1-octen-3-ol and 4-methylphenol on Culicoides midge numbers collected with suction light traps in South Africa. Vet. Parasitol. $175(1-2)$ 182-186, http://dx.doi.org/10.1016/j.vetpar.2010.09.010

Viennet, E., Garros, C., Gardès, L., Rakotoarivony, I., Allène, X., Lancelot, R., Crochet D., Moulia, C., Baldet, T., Balenghien, T., 2013. Host preferences of Palaearctic Culicoides biting midges: implications for transmission of orbiviruses. Med. Vet. Entomol. 27 (3), 255-266, http://dx.doi.org/10.1111/j.1365-2915.2012.01042.x

Viennet, E., Garros, C., Lancelot, R., Allène, X., Gardès, L., Rakotoarivony, I., Crochet, D., Delécolle, J.-C., Moulia, C., Baldet, T., Balenghien, T., 2011. Assessment of vector/host contact: comparison of animal-baited traps and UV-light/suction trap for collecting Culicoides biting midges (Diptera: Ceratopogonidae), vectors of Orbiviruses. Parasit. Vectors 4, 119, http://dx.doi.org/10.1186/1756-3305-4119

Votypka, J., Synek, P., Svobodova, M., 2009. Endophagy of biting midges attacking cavity nesting birds. Med. Vet. Entomol. 23 (3), 277-280.

Wieser-Schimpf, L., Foil, L.D., Holbrook, F.R., 1991. Effect of carbon dioxide on the collection of adult Culicoides spp. (Diptera: Ceratopogonidae) by a new modification of black light New Jersey light traps. J. Am. Mosquito Contr. 7 (3), 462-466.

Zimmer, J.-Y., Haubruge, E., Francis, F., Bortels, J., Simonon, G., Losson, B., Mignon, B., Paternostre, J., De Deken, R., De Deken, G., Deblauwe, I., Fassotte, C., Cors, R. Defrance, T., 2008. Breeding sites of bluetongue vectors in northern Europe. Vet. Rec. 162 (131), http://dx.doi.org/10.1136/vr.162.4.131

Zimmer, J.-Y., Losson, B., Saegerman, C., Haubruge, E., 2009. Ecologie et distribution des espèces de Culicoides Latreille 1809 (Diptera: Ceratopogonidae) à proximité d'une exploitation bovine en Belgique. Ann. Soc. Entomol. Fr. 45 (3), 393-400.
Zimmer, J.-Y., Saegerman, C., Losson, B., Beckers, Y., Haubruge, E., Francis, F., 2013a Chemical composition of silage residues sustaining the larval development of the Culicoides obsoletus/Culicoides scoticus species (Diptera: Ceratopogonidae). Vet. Parasitol. 191, 197-201, http://dx.doi.org/10.1016/j.vetpar.2012.08.014

Zimmer, J.-Y., Smeets, F., Simonon, G., Fagot, J., Haubruge, E., Francis, F., Losson, B., 2013b. Are bogs reservoirs for emerging disease vectors? Evaluation of Culicoides populations in the Hautes Fagnes Nature Reserve (Belgium). PLoS One 8, e66893, http://dx.doi.org/10.1371/journal.pone.0066893

Zimmer, J.-Y., Losson, B., Saegerman, C., Haubruge, E., Francis, F., 2013c. Breeding sites and species association of the main Bluetongue and Schmallenberg virus vectors, the Culicoides species (Diptera: Ceratopogonidae), in northern Europe. Ann. Soc. Entomol. Fr. 49 (3), 335-344.

Zimmer, J.-Y., Losson, B., Saegerman, C., Kirschvink, N., Haubruge, E., Francis, F. 2013d. Comparaison des populations de Culicoides Latreille 1809 (Diptera: Ceratopogonidae) présentes au sein d'une bergerie belge et d'une prairie ovine associée. Ann. Soc. Entomol. Fr. 49 (4), 446-459.

Zimmer, J.-Y., Haubruge, E., Francis, F., 2014a. Synthèse bibliographique: l'écologie larvaire des culicoïdes (Diptera: Ceratopogonidae). Biotechnol. Agron. Soc. Environ. 18 (2), 301-312.

Zimmer, J.-Y., Saegerman, C., Martinelle, L., Losson, B., Leroy, P., Haubruge, E. Francis, F., 2014b. Les porcheries: réservoirs des Culicoides (Diptera: Ceratopogonidae), vecteurs des virus de la Maladie de la Langue bleue et de Schmallenberg? Biotechnol. Agron. Soc. Environ. 18 (4), 480-487.

Zimmer, J.-Y., Brostaux, Y., Haubruge, E., Francis, F., 2014c. Larval development sites of the main Culicoides species (Diptera: Ceratopogonidae) in northern Europe and distribution of coprophilic species larvae in Belgian pastures. Vet. Parasitol. 205, 676-686, http://dx.doi.org/10.1016/j.vetpar.2014.08.029. 